UNIVERSITE DE LAUSANNE - FACULTE DE BIOLOGIE ET DE MEDECINE

Département de Médecine

Service de médecine interne

Pulmonary-Artery Pressure and Exhaled Nitric Oxide in Bolivian and Caucasian High

Altitude Dwellers

THESE

préparée sous la direction du Professeur associé Urs SCHERRER

et présentée à la Faculté de biologie et de médecine de

l'Université de Lausanne pour l'obtention du grade de

DOCTEUR EN MEDECINE

Par

Marcos SCHWAB

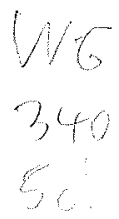

Lausanne

2009

Biblotheque Unversilaire de Médecine / BiUIV

CHUV BHOS - Bugnon 46

CH-1011 I_ausanne 


\section{Ecole Doctorale \\ Doctorat en médecine}

\section{Imprimatur}

Vu le rapport présenté par le jury d'examen, composé de

Directeur de thèse Monsieur le Professeur associé Urs Scherrer

Co-Directeur de thèse

Expert Monsieur le Professeur Bernard Waeber

Directrice de l'Ecole Madame le Professeur Stephanie Clarke doctorale

la Commission MD de l'Ecole doctorale autorise l'impression de la thèse de

Monsieur Marcos Schwab

intitulée

Pulmonary-artery pressure and exhaled nitric oxide in bolivian and caucasian high altitude dwellers

Lausanne, le 31 mars 2009

pour Le Doyen
de la Faculté de Biologie et de Médecine

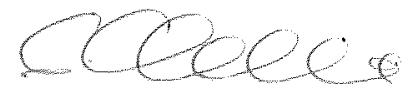

Madame le Professeur Stephanie Clarke Directrice de l'Ecole doctorale 


\section{Rapport de synthèse}

Plusieurs études suggèrent que les populations vivant en haute altitude sont mieux protégées contre 1'hypertension pulmonaire hypoxique que celles originaires de la plaine. Cependant, les mécanismes sous-jacents ne sont pas bien compris. Chez les Tibétains, la synthèse augmentée par le système respiratoire de monoxyde d'azote (NO) atténue l'hypertension pulmonaire hypoxique. Il a été spéculé que ce mécanisme pourrait représenter un mode généralisé d'adaptation à la haute altitude, mais il n'existe pas de preuve directe qui confirme cette hypothèse. Nous avons donc mesuré la pression artérielle pulmonaire (par échocardiographie Doppler) ainsi que la concentration du NO dans l'air exhalé chez 34 Boliviens en bonne santé, nés et ayant toujours vécus en haute altitude $(3600 \mathrm{~m})$ et chez 34 Caucasiens apparentés pour l'âge et le sexe, nés en basse altitude mais vivant depuis de nombreuses années à cette même haute altitude (3600 mètres). La pression artérielle pulmonaire (24.3 \pm 5.9 vs. $24.7 \pm 4.9 \mathrm{~mm}$ $\mathrm{Hg}$ ) et le NO exhalé (19.2 \pm 7.2 vs. $22.5 \pm 9.5 \mathrm{ppb}$ ) étaient similaires chez les Boliviens et les Caucasiens. Il n'y avait aucune corrélation entre la pression artérielle pulmonaire et le NO respiratoire dans les deux groupes. Ces résultats ne fournissent donc aucune évidence que les Boliviens nés en haute altitude sont mieux protégés contre l'hypertension pulmonaire hypoxique que les Caucasiens nés à basse altitude. Cela suggère que l'atténuation de l'hypertension pulmonaire par une synthèse accrue de NO respiratoire ne représente pas un mode universel d'adaptation des populations à la haute altitude. 


\title{
Pulmonary-Artery Pressure and Exhaled Nitric Oxide in Bolivian and Caucasian High Altitude Dwellers
}

\author{
Marcos Schwab, ${ }^{1}$ Pierre-Yves Jayet, ${ }_{1}^{1}$ Thomas Stuber, ${ }^{2}$ Carlos E. Salinas, ${ }^{3}$ Jonathan Bloch, ${ }^{1}$ \\ Hilde Spielvogel, ${ }^{3}$ Mercedes Villena, ${ }^{3}$ Yves Allemann, ${ }^{2}$ Claudio Sartori, ${ }^{1}$ and Urs Scherrer ${ }^{1}$
}

\begin{abstract}
Schwab, Marcos, Pierre-Yves Jayet, Thomas Stuber, Carlos Salinas, Jonathan Bloch, Hilde Spielvogel, Mercedes Villena, Yves Allemann, Claudio Sartori, and Urs Scherrer. Pulmonary-artery pressure and exhaled nitric oxide in Bolivian and Caucasian high altitude dwellers. High Alt. Med. \& Biol. 9:295-299, 2008.-There is evidence that high altitude populations may be better protected from hypoxic pulmonary hypertension than low altitude natives, but the underlying mechanism is incompletely understood. In Tibetans, increased pulmonary respiratory NO synthesis attenuates hypoxic pulmonary hypertension. It has been speculated that this mechanism may represent a generalized high altitude adaptation pattern, but direct evidence for this speculation is lacking. We therefore measured systolic pulmonary-artery pressure (Doppler echocardiography) and exhaled nitric oxide (NO) in 34 healthy, middle-aged Bolivian high altitude natives and in 34 age- and sex-matched, well-acclimatized Caucasian low altitude natives living at high altitude $(3600 \mathrm{~m})$. The mean $\pm \mathrm{SD}$ systolic right ventricular to right atrial pressure gradient $(24.3 \pm 5.9 \mathrm{vs.} 24.7 \pm 4.9 \mathrm{mmHg})$ and exhaled $\mathrm{NO}(19.2 \pm 7.2 \mathrm{vs.} 22.5 \pm$ $9.5 \mathrm{ppb}$ ) were similar in Bolivians and Caucasians. There was no relationship between pulmonary-artery pressure and respiratory NO in the two groups. These findings provide no evidence that Bolivian high altitude natives are better protected from hypoxic pulmonary hypertension than Caucasian low altitude natives and suggest that attenuation of pulmonary hypertension by increased respiratory NO synthesis may not represent a universal adaptation pattern in highaltitude populations.
\end{abstract}

Key Words: nitric oxide; pulmonary hypoxic vasoconstriction; altitude

\section{Introduction}

N INCREASE IN pulmonary-artery pressure is a hallmark of the physiological response to the ambient lack of oxygen and occurs very rapidly after high altitude exposure (Naeije, 1992). In chronic hypoxic states, sustained pulmonary vasoconstriction and/or vascular remodeling of the pulmonary vasculature may lead to sustained pulmonary hypertension and its associated complications (Penaloza and Arias-Stella, 2007). Compared to European or North American low altitude natives, hypoxic pulmonary hypertension has been reported to be attenuated in Andean high altitude populations and even more so in Tibetans (Penaloza and Arias-Stella, 2007), but the underlying mechanism is not clear.

Pulmonary respiratory nitric oxide (NO) might represent a candidate mechanism. While it is well established that NO synthesized by the pulmonary vascular endothelium plays an important role in the regulation of pulmonary-artery pressure during hypoxia, more recent evidence suggests that NO synthesized by the respiratory epithelium also plays a role (Settergren et al., 1998; Vaughan et al, 2003). In rabbits, inhibition of alveolar epithelial NO synthesis increases the pulmonary-artery pressure response to hypoxia (Vaughan et al., 2003). In healthy Caucasians, short-term exposure to high altitude increases exhaled pulmonary NO (a marker of NO release in the distal airways) (Duplain et al, 2000). In Caucasians prone to high altitude pulmonary edema, the hypoxia-induced stimulation of exhaled $\mathrm{NO}$ is impaired and contributes to the exaggerated altitude-induced pulmonary hypertension that characterizes these subjects (Duplain et al., 2000; Busch et al., 2001). Recently, pulmonary exhaled NO

\footnotetext{
${ }^{1}$ Department of Internal Medicine and Botnar Centre for Extreme Medicine, University Hospital, Lausanne, Switzerland

${ }^{2}$ Swiss Cardiovascular Center Bern, University Hospital, Bem, Switzerland.

${ }^{3}$ Instituto Boliviano de Biología de Altura, La Paz, Bolivia.
} 
was found to be higher in Tibetan and Bolivian high altitude dwellers than in low altitude residents in the United States (Beall et al., 2001). Moreover, exhaled NO explained part of the variation of pulmonary-artery pressure at high altitude in Tibetans (Hoit et al., 2005). It has been speculated (Beall et al., 2001) that increased pulmonary respiratory NO synthesis may represent a specific high-altitude adaptation pattern that helps to maintain pulmonary-artery pressure in high altitude populations within normal limits, but direct evidence for this speculation is lacking. We therefore measured the systolic right ventricular to right atrial pressure gradient and exhaled NO in healthy Bolivian high altitude dwellers and Caucasian low altitude natives living at the same high altitude location (3600 m).

\section{Methods}

\section{Study design}

Thirty-four healthy Bolivians (10 women, 24 men), born and permanently living at high altitude (3600 to $4000 \mathrm{~m}$ ), mean \pm SD, age, $36 \pm 9$ yr (range 23 to 53), and 34 healthy well-acclimatized Caucasians (13 women, 21 men), age, $38 \pm$ 7 yr (range 25 to 56), living at the same altitude, were included in the study. All Bolivian subjects had typical Aymara surnames and self-identified themselves as Aymaras. The Caucasian subjects had lived at this altitude for $6 \pm 7 \mathrm{yr}$ (range 1 to 35). The subjects were recruited by advertising in local health centers and schools. All subjects were free of structural heart disease (as assessed by physical examination and Doppler chocardiography), and had normal pulmonary function tests; none had suffered from upper or lower respiratory tract infection during the last 4 weeks preceding the study. None of the subjects were smokers, were taking medications, or had a history of atopy or high altitude pulmonary edema. All measurements were made at the Instituto Boliviano de Biología de Altura in La Paz, Bolivia ( $3600 \mathrm{~m}$, barometric pressure $493 \mathrm{mmHg}$ ). The experimental protocol was approved by the institutional review board on human investigation of the University of San Andrés, La Paz, Bolivia, and the University of Lausanne, Switzerland. All subjects provided written informed consent.

\section{Exhaled nitric oxide}

The measurements were made in the sitting position with a hand-held electrochemical analyzer (NIOX MINO ${ }^{\circledR}$, Aerocrine, Solna, Sweden) (Hemmingsson et al., 2004), using standard quality criteria (ATS/ERS, 2005). The reported values represent the mean of two determinations that varied one from another by $<10 \%$. In a subgroup of 37 subjects studied on two different occasions 3 to 15 days apart, the intraindividual variability of exhaled NO was $0.3 \pm 3.7 \mathrm{ppb}$. For comparison across altitudes, exhaled NO was also expressed in nanometers of mercury ( $\mathrm{nmHg}$ ) by multiplying $\mathrm{NO}$ measured in parts per billion by (barometric pressure 47) $/ 1000$.

\section{Doppler echocardiography}

Transthoracic Doppler echocardiography was performed in all subjects to rule out structural heart disease. To measure pulmonary-artery pressure and cardiac output, echocardiographic recordings were obtained with a real-time, phased array sector scanner (Acuson Cypress, Siemens, Germany) with an integrated color Doppler system and transducers containing crystal sets for 2D-imaging (3.6 MHz) and for continuous- and pulsed-wave Doppler recording $(2.15$ $\mathrm{MHz}$ ), as described earlier (Scherrer et al., 1996; Oh, 1999; Allemann et al., 2000). The recordings were stored on magneto-optical discs for off-line analysis by an investigator who was unaware of the subject's identity. After tricuspid regurgitation had been localized with Doppler color flow imaging, the peak flow velocity of the transtricuspid jet was measured with the use of continuous-wave Doppler, and the pressure gradient between the right ventricle and the right atrium was calculated by use of the modified Bernoulli equation. All reported values represent the mean of at least three measurements. Right ventricular to right atrial pressure gradient estimations of pulmonary-artery pressure have been validated against invasive measurements at high altitude (Allemann et al., 2000).

The intra- and interobserver variability for the systolic right ventricular to right atrial pressure gradient measurements was $1.5 \pm 1.2 \mathrm{mmHg}$ and $1.6 \pm 2.2 \mathrm{mmHg}$, respectively $(n=30)$ and, for the cardiac output measurements, $10.7 \pm 10.2 \%$ and $7.2 \pm 4 \%$, respectively $(n=30)$. Cardiac index was calculated by dividing cardiac output (L/min) by the body surface area $\left(\mathrm{m}^{2}\right)$.

\section{Arterial oxygen saturation and heart rate}

Transcutaneous arterial oxygen saturation and heart rate were measured at a fingertip with a pulse oxymeter (OxiMax®N-595, Nellcor, Pleasanton, USA).

\section{Statistical analysis}

Statistical analysis was done with the JMP software package (SAS Institute, Inc., USA). The two-tailed $t$-test was used for single comparisons between the groups. Relations between variables were analyzed by calculating Pearson's product-moment correlation coefficient. A value of $p<0.05$ was considered to indicate statistical significance. Data are expressed as means $\pm \mathrm{SD}$.

\section{Results}

As expected, both groups displayed hypoxemia, which was similar in Bolivian and Caucasian high altitude dwellers (mean arterial oxygen saturation was $92.4 \pm 3.2 \%$ and $92.5 \pm$ $2.4 \%$ in Bolivians and Caucasians, respectively, $p=0.85$ ).

Figure 1 shows that, in contrast to our expectations, the systolic right ventricular to right atrial pressure gradient was similar $(p=0.84)$ in Bolivian high altitude dwellers (24.3 \pm $5.9 \mathrm{mmHg}$, range 11 to $35 \mathrm{mmHg}$ ) and well-adapted Caucasians living at high altitude $(24.7 \pm 4.9 \mathrm{mmHg}$, range 17 to $37 \mathrm{mmHg}$ ). The cardiac index was also comparable in the two groups $\left(2.2 \pm 0.5 \mathrm{~L} / \mathrm{min} / \mathrm{m}^{2}\right.$, range 1.4 to $3.2 \mathrm{~L} / \mathrm{min} / \mathrm{m}^{2}$, vs. $2.4 \pm 0.6 \mathrm{~L} / \mathrm{min} / \mathrm{m}^{2}$, range 1.3 to 3.8 in Bolivians and Caucasians, respectively, $p=0.53$ ).

Figure 2 shows that the NO concentration in the exhaled air was also similar $(p=0.11)$ in Bolivians [19.2 $\pm 7.2 \mathrm{ppb}$ $(8.6 \pm 3.2 \mathrm{nmHg})$, range 8 to $41 \mathrm{ppb}]$ and Caucasians [(22.5 \pm $9.5 \mathrm{ppb}(10.0 \pm 4.2 \mathrm{nmHg})$, range 9 to $52 \mathrm{ppb})]$. No significant relationship existed between the systolic right ventricular to right atrial pressure gradient and the exhaled NO in 


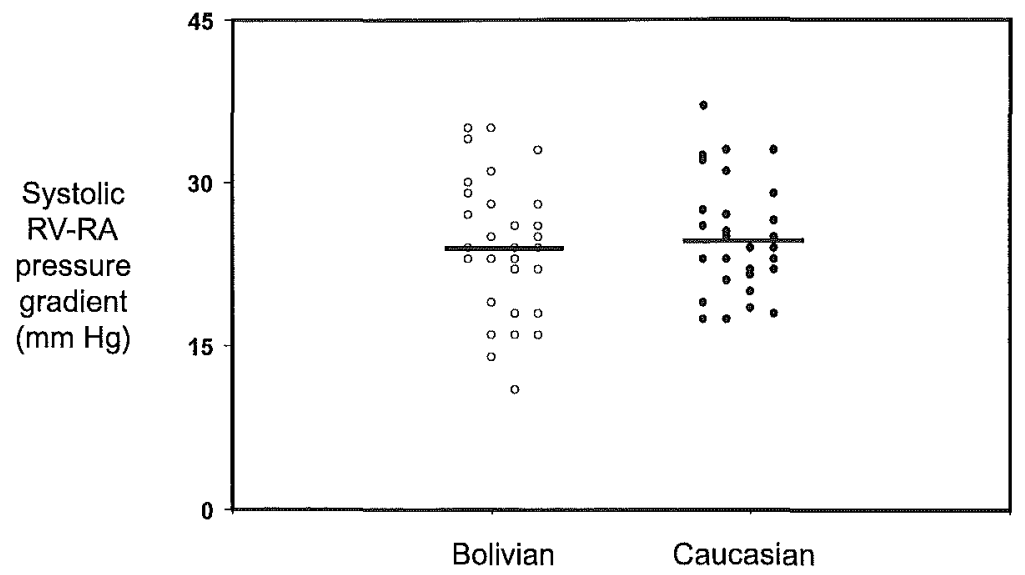

FIG. 1. Systolic right ventricular to right atrial (RV-RA) pressure gradient in 34 healthy Bolivian high altitude natives and 34 age- and sex-matched Caucasian low altitude natives permanently living at high altitude ( $3600 \mathrm{~m})$. Horizontal lines represent the mean value. $p=0.84$.

the two groups $(r=0.14, p=0.44$ and $r=0.19, p=0.29$ in Bolivians and Caucasians, respectively; see Fig. 3). Also, no detectable relationship existed between exhaled NO and cardiac index in the two groups $(r=0.1, p=0.60$ and $r=0.16$, $p=0.48$, in Bolivians and Caucasians, respectively).

Finally, in the Caucasians there was no relationship between the number of years spent at high altitude and pulmonary-artery pressure $(r=0.28, p=0.12)$ or exhaled nitric oxide $(r=0.27, p=0.14)$.

\section{Discussion}

There is evidence that high altitude populations are generally better protected from hypoxic pulmonary hypertension than Caucasian low altitude natives (Penaloza and Arias-Stella, 2007). Recent data suggest that this protection might be related to increased pulmonary NO synthesis (Beall et al., 2001). Here we found that pulmonary-artery pressure was similar in Bolivian high altitude natives and welladapted Caucasian low altitude natives living at the same high altitude location. Moreover, exhaled respiratory NO did not appear to be a determinant of pulmonary-artery pressure, because no detectable relationship existed between these two variables in this relatively large group of healthy people living at high altitude.

The finding that Bolivian high altitude dwellers were not protected from pulmonary hypertension was surprising, since we recently found that pulmonary-artery pressure was significantly lower in Bolivian than in Caucasian children living at the same altitude (Stuber et al., 2008). The reasons for this discrepancy are not clear, but could possibly be related to a positive selection with regard to high altitude tolerance among Caucasians deciding to spend their lives at high altitude. The present echocardiographic estimations of pulmonary-artery pressure in healthy Bolivian high altitude natives were similar to invasive measurements reported in healthy Peruvian high altitude dwellers studied at a comparable altitude (Hultgren et al., 1965), suggesting that these findings may be valid for Andean high altitude natives in general. The echocardiographic estimations of pulmonaryartery pressure in these healthy Caucasian and Bolivian high altitude dwellers studied at $3600 \mathrm{~m}$ were roughly 7 to 8

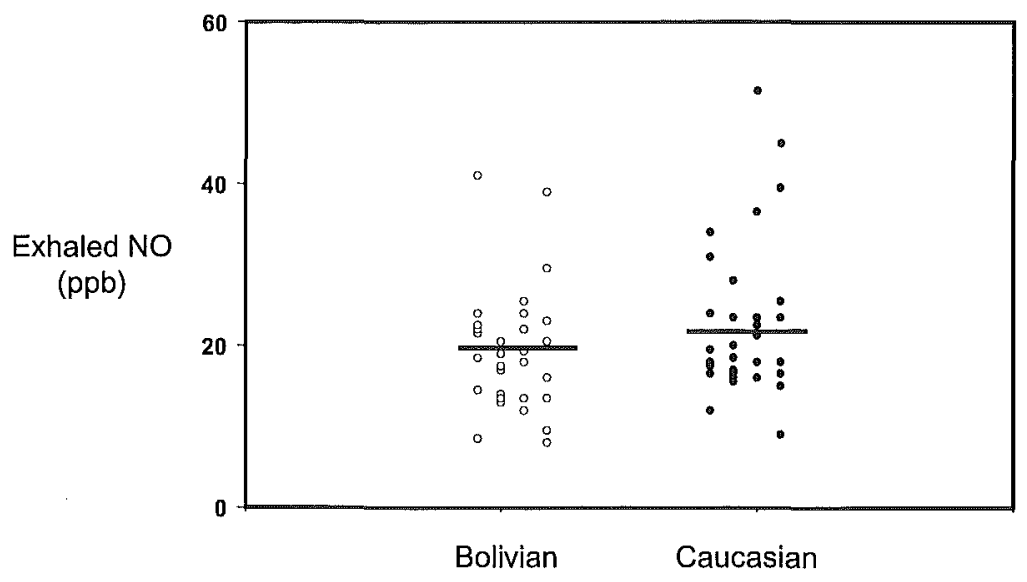

FIG. 2. Exhaled respiratory nitric oxide (NO) in 34 healthy Bolivian high altitude natives and 34 age- and sex-matched Caucasian low altitude natives permanently living at high altitude $(600 \mathrm{~m})$. Horizontal lines represent the mean value. $p=$ 0.11 . 


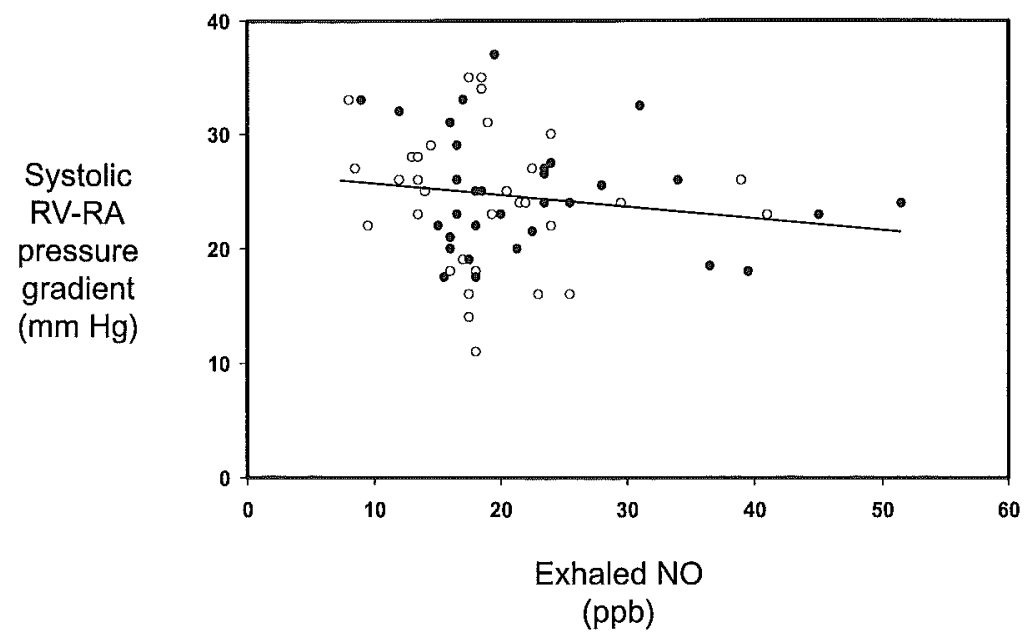

FIG. 3. Relationship between the systolic right ventricular to right atrial (RV-RA) pressure gradient and exhaled respiratory nitric oxide (NO) in 34 healthy Bolivian high altitude natives (open circles) and 34 age- and sex-matched Caucasian low altitude natives (filled circles) permanently living at high altitude $(3600 \mathrm{~m}) . R^{2}=0.0221, p=0.23$.

mmHg higher than those reported in a large North American population sample of comparable age studied at sea level, but were below the upper $95 \%$ limit found in this population (McQuillan et al., 2001).

In an earlier study, exhaled NO was reported to be higher in Bolivian high altitude dwellers than in North Americans living at low altitude (Beall et al., 2001). In the present study, exhaled NO was comparable in well-adapted Caucasians and Bolivian high altitude natives. Moreover, acute high altitude exposure increases exhaled NO in healthy Caucasian low altitude natives (Duplain et al., 2000; Busch et al., 2001). Taken together, these observations suggest that in this earlier study the lower exhaled NO concentration in the North Americans was related to the fact that they were studied at low altitude, rather than to ethnicity. In line with this concept, exhaled NO was recently found to be similar in Bolivian and Caucasian children permanently living at high altitude (Stuber et al., 2008).

The present findings differ from data in Tibetans, in whom exhaled NO explained a small fraction of the variation of pulmonary-artery pressure and cardiac index (Hoit et al., 2005). This difference in the role of exhaled NO in cardiovascular regulation between Tibetans and Bolivians could be related to ethnicity and thereby represents an additional example of a different adaptive mechanism to high altitude among high-altitude populations (Beall et al., 2002). Interestingly, pulmonary-artery pressure is lower in Tibetan than in Andean high altitude residents living at the same altitude (Penaloza and Arias-Stella, 2007), and it appears possible that respiratory NO may represent a contributory mechanism.

While these findings do not provide evidence for a role of respiratory epithelial NO in the regulation of pulmonaryartery pressure during long-term exposure to hypoxia in Bolivians and Caucasians, they do not exclude the possibility that pulmonary vascular endothelial NO may represent a determinant of the long-term regulation of pulmonary-artery pressure in high altitude dwellers. Exhaled NO does not reflect pulmonary vascular endothelial NO synthesis (Sartori et al., 1999; Cook et al., 2003), and endothelial nitric oxide synthase (eNOS) polymorphisms associated with augmented vascular NO synthesis are related to attenuated hypoxic pulmonary hypertension in high altitude natives in Ladhak (Ahsan et al., 2004), whereas eNOS polymorphisms associated with defective NO synthesis predispose to exaggerated hypoxic pulmonary vasoconstriction and high altitude pulmonary edema (Droma et al., 2002; Ahsan et al., 2004). Consistent with this concept, in Tibetans increased plasma concentration of bioactive NO products is associated with a higher systemic blood flow (Erzurum et al., 2007).

Finally, the present findings in chronically hypoxic Caucasian high altitude dwellers contrast with observations made during short-term exposure to hypoxia, where low levels of exhaled NO were associated with exaggerated hypoxic pulmonary hypertension (Duplain et al., 2000; Busch et al., 2001; Vaughan et al., 2003). Taken together, these earlier and the present observations could be consistent with the hypothesis that in Caucasians respiratory epithelial NO may be a determinant of the pulmonary-artery pressure during the short term, but not during long-term exposure to high altitude.

\section{Acknowledgments}

This work was supported by grants from the Swiss National Science Foundation, the Cloëtta Foundation, the Novartis Foundation, the Emma Muschamp Foundation, and the Placide Nicod Foundation.

We are indebted to Mrs. Catherine Romero and Dr. Armando Rodriguez for invaluable help with these studies and to Elisa Maldonado-Holmertz and Tryggve Hemmingsson for their advice and technical support.

\section{Disclosures}

The authors have no conflicts of interest or financial ties to disclose. 


\section{References}

Ahsan A., Charu R., Pasha M.A., Norboo T., Afrin F., and Baig M.A. (2004). eNOS allelic variants at the same locus associate with HAPE and adaptation. Thorax. 59:1000-1002.

Allemann Y., Sartori C., Lepori M., Pierre S., Melot C., Naeije R., Scherrer U., and Maggiorini M. (2000). Echocardiographic and invasive measurements of pulmonary artery pressure correlate closely at high altitude. Am. J. Physiol. Heart Circ. Physiol. 279:H2013-H2016.

ATS/ERS Recommendations for Standardized Procedures for the Online and Offline Measurement of Exhaled Lower Respiratory Nitric Oxide and Nasal Nitric Oxide, 2005. Am. J. Respir. Crit. Care Med. 171: 912-930.

Beall C.M., Decker M.J., Brittenham G.M., Kushner I., Gebremedhin A., and Strohl K.P. (2002). An Ethiopian pattern of human adaptation to high-altitude hypoxia. Proc. Natl. Acad. Sci. U.S.A. 99:17215-17218.

Beall C.M., Laskowski D., Strohl K.P., Soria R., Villena M., Vargas E., Alarcon A.M., Gonzales C., and Erzurum S.C. (2001). Pulmonary nitric oxide in mountain dwellers. Nature. 414:411-412.

Busch T., Bartsch P., Pappert D., Grunig E., Hildebrandt W., Elser H., Falke K.J., and Swenson E.R. (2001). Hypoxia decreases exhaled nitric oxide in mountaineers susceptible to high-altitude pulmonary edema. Am. J. Respir. Crit. Care Med. 163:368-373.

Cook S., Vollenweider P., Menard B., Egli M., Nicod P., and Scherrer U. (2003). Increased eNO and pulmonary iNOS expression in eNOS null mice. Eur. Respir. J. 21:770-773.

Droma Y., Hanaoka M., Ota M., Katsuyama Y., Koizumi T., Fujimoto K., Kobayashi T., and Kubo K. (2002). Positive association of the endothelial nitric oxide synthase gene polymorphisms with high-altitude pulmonary edema. Circulation. 106:826-830.

Duplain H., Sartori C., Lepori M., Egli M., Allemann Y., Nicod P., and Scherrer U. (2000). Exhaled nitric oxide in high-altitude pulmonary edema: role in the regulation of pulmonary vascular tone and evidence for a role against inflammation. Am. J. Respir. Crit. Care Med. 162:221-224.

Erzurum S.C., Ghosh S., Janocha A.J., Xu W., Bauer S., Bryan N.S., Tejero J., Hemann C., Hille R., Stuehr D.J., et al. (2007). Higher blood flow and circulating NO products offset highaltitude hypoxia among Tibetans. Proc. Natl. Acad. Sci. U.S.A. 104:17593-17598.

Hemmingsson T., Linnarsson D., and Gambert R. (2004). Novel hand-held device for exhaled nitric oxide analysis in research and clinical applications. J. Clin. Monit. Comput. 18:379-387.

Hoit B.D., Dalton N.D., Erzurum S.C., Laskowski D., Strohl K.P., and Beall C.M. (2005). Nitric oxide and cardiopulmonary hemodynamics in Tibetan highlanders. J. Appl. Physiol. 99:1796-1801.
Hultgren H.N., Kelly J., and Miller H. (1965). Effect of oxygen upon pulmonary circulation in acclimatized man at high altitude. J. Appl. Physiol. 20:239-243.

McQuillan B.M., Picard M.H., Leavitt M., and Weyman A.E. (2001). Clinical correlates and reference intervals for pulmonary artery systolic pressure among echocardiographically normal subjects. Circulation. 104:2797-2802.

Naeije R. (1992). Pulmonary circulation in hypoxia. Int. J. Sports Med. 13 Suppl. 1:S27-S30.

Oh J.S., and Tajik A.J. (1999). The Echo Manual. Lippincott Williams \& Wilkins, Philadelphia; pp 59-62.

Penaloza D., and Arias-Stella J. (2007). The heart and pulmonary circulation at high altitudes: healthy highlanders and chronic mountain sickness. Circulation. 115:1132-1146.

Sartori C., Lepori M., Busch T., Duplain H., Hildebrandt W., Bartsch P., Nicod P., Falke K.J., and Scherrer U. (1999). Exhaled nitric oxide does not provide a marker of vascular endothelial function in healthy humans. Am. J. Respir. Crit. Care Med. 160:879-882.

Scherrer U., Vollenweider L., Delabays A., Savcic M., Eichenberger U., Kleger G.R., Fikrle A., Ballmer P.E., Nicod P., and Bärtsch P. (1996). Inhaled nitric oxide for high-altitude pulmonary edema. New Engl. J. Med. 334:624-629.

Settergren G., Angdin M., Astudillo R., Gelinder S., Liska J., Lundberg J.O., and Weitzberg E. (1998). Decreased pulmonary vascular resistance during nasal breathing: modulation by endogenous nitric oxide from the paranasal sinuses. Acta Physiol. Scand. 163:235-239.

Stuber, T., Sartori C., Salinas-Salmon C., Hutter D., Thalmann S., Turini P., Jayet P.Y., Schwab M., Sartori-Cucchia C., Villena M., Scherrer U., and Allemann Y. (2008). Respiratory nitric oxide and pulmonary artery pressure in children of Aymara and European ancestry at high altitude. Chest. 134:996-1000.

Vaughan D.J., Brogan T.V., Kerr M.E., Deem S., Luchtel D.L., and Swenson E.R. (2003). Contributions of nitric oxide synthase isozymes to exhaled nitric oxide and hypoxic pulmonary vasoconstriction in rabbit lungs. Am. J. Physiol. Lung Cell Mol. Physiol. 284:L834-843.

Address correspondence to: Dr. Urs Scherrer

Department of Internal Medicine, BH 10.642

Centre Hospitalier Universitaire

Vaudois, CH-1011 Lausanne, Switzerland

E-mail: Urs.Scherrer@chuv.ch

Received July 10, 2008; accepted in final form July 27, 2008. 